Article

\title{
Importance of the Local Environment on Nutrient Cycling and Litter Decomposition in a Tall Eucalypt Forest
}

\author{
Jessie C. Buettel *(D), Elise M. Ringwaldt, Mark J. Hovenden and Barry W. Brook ${ }^{(D)}$ \\ Discipline of Biological Sciences, School of Natural Sciences, University of Tasmania, Hobart 7000, Australia; \\ Elise.Ringwaldt@utas.edu.au (E.M.R.); Mark.Hovenden@utas.edu.au (M.J.H.); Barry.Brook@utas.edu.au (B.W.B.) \\ * Correspondence: jessie.buettel@utas.edu.au; Tel.: +614-57-666-016
}

Received: 28 February 2019; Accepted: 3 April 2019; Published: 16 April 2019

check for updates

\begin{abstract}
The relative abundance of nitrogen-fixing species has been hypothesised to influence tree biomass, decomposition, and nitrogen availability in eucalypt forests. This prediction has been demonstrated in experimental settings (two-species mixtures) but is yet to be observed in the field with more realistically complex communities. We used a combination of (a) field measurements of tree-community composition, (b) sampling of soil from a subset of these sites (i.e., the local environment), and (c) a decomposition experiment of forest litter to examine whether there is a local-scale effect of the nitrogen-fixing Acacia dealbata Link (presence and abundance) on nitrogen availability, and whether increases in this essential nutrient led to greater biomass of the canopy tree species, Eucalyptus obliqua L'Hér. Average A. dealbata tree size was a significant predictor of forest basal area in 24 plots (12\% deviance explained) and, when combined with average distance between trees, explained 29.1\% variance in E. obliqua biomass. However, static patterns of local nitrogen concentration were unrelated to the presence or size of $A$. dealbata, despite our experiments showing that $A$. dealbata leaf litter controls decomposition rates in the soil (due to three times higher N). Such results are important for forest management in the context of understanding the timing and turnover of shorter-lived species like acacias, where higher $\mathrm{N}$ (through either litter or soil) might be better detected early in community establishment (when growth is faster and intraspecific competition more intense) but with that early signal subsequently dissipated.
\end{abstract}

Keywords: forests; nutrients; disturbance; management; diversity; biomass

\section{Introduction}

Understanding the mechanisms that control the biomass and density of trees in forests is important for ecological, economic, and conservation motivations [1]. For instance, growing forests sequester substantial amounts of carbon [2], and as global atmospheric carbon dioxide $\left(\mathrm{CO}_{2}\right)$ continues to rise, understanding tree growth and the mechanisms that drive carbon accumulation and storage has become a pressing issue. Abiotic factors like climate, soil type, and disturbance frequency are known to be among the major determinants of the productivity of plant communities [3]. However, in recent decades, interest has shifted towards how community properties (e.g., number and relative abundance of species), and functional traits (e.g., [4]), influence productivity [5]. This is particularly important in studies of community structure, because these features are amenable to experimentation and as a management tool. Additionally, since different plant species vary in their nutrient requirements [6], it is possible that nutrient cycling is a fundamental feature contributing to the observed link between diversity and productivity.

The availability of nitrogen $(\mathrm{N})$ limits productivity in many terrestrial ecosystems, and its increase typically promotes plant-community productivity $[7,8]$. This effect is further facilitated through 
complementarity, because differences in N-use efficiency lead to positive feedbacks in N-cycling rates [9]. Nitrogen cycling is heavily dependent on the input and output of various forms of $\mathrm{N}[10,11]$, which is often supplied in various quantities by different plant species (and their litter). The plant litter can comprise a mixture of fine detritus (e.g., leaf litter, bark, twigs) and coarse material (branches and whole stems of fallen trees), which are then decomposed and transformed into available nutrients, such as nitrogen [12], via ammonification, nitrification, and $\mathrm{N}$ mineralisation. Nitrification is the dominant process in most soils, where nitrifying organisms are often constrained by, and are dependent on, the rate of ammonification [13]. Because of the scarcity of $\mathrm{N}$ in soils, soil- $\mathrm{N}$ transformations have a strong influence on the potential productivity of an ecosystem [14,15].

It is well known that decomposition rates can vary due to differences in leaf quality (C:N ratio) among plant species, and often increase when litter of different species is combined [16,17] due to complementary stimulation among microbial groups [18]. For example, sclerophyllous eucalypts produce litter that has low nutrient concentrations and low rates of decomposition [19] whereas, by contrast, the litter of $\mathrm{N}$-fixing acacias has comparatively high $\mathrm{N}$ concentrations and decomposition rates $[20,21]$. This has led to speculation that Australian forest communities containing species with more readily decomposable and nutrient-rich litter (such as Acacia spp.) might have higher litter decomposition rates than those with Eucalyptus litter alone [22,23]. However, this idea has yet to be explored in natural forest systems or linked to overall tree size and biomass.

Here we use field and laboratory data to determine the local-scale effect of an $\mathrm{N}$-fixing tree species (Acacia dealbata Link) on the size and total biomass of the dominant eucalypt species (Eucalyptus obliqua L'Hér) in a tall hardwood forest community in Tasmania, southern Australia. We used a combination of:

1. Field measurements on the standing pattern (size structure, density, and species composition) of mature trees, used as a proxy for productivity;

2. Sampling and analysis of the soil-nutrient composition in the local environment (i.e., across field sites) and assessment of its relationship to site biomass; and

3. Evaluation of the association between forest-litter quality (different species mixes) and quantity, and the rate of decomposition, as a measure of turnover.

\section{Materials and Methods}

\subsection{Study Site}

The field sites were located in a tall eucalypt forest at an altitudinal range of $310-440 \mathrm{~m}$ above sea level, on the foothills of Mount Wellington, in south-eastern Tasmania ( $\left.42.895^{\circ} \mathrm{S}-147.268^{\circ} \mathrm{E}\right)$. Vegetation in the region is dominated by E. obliqua, a widespread and abundant tall tree found across south-eastern Australia, with the occasional occurrence of Eucalyptus regnans F.Muell and Eucalyptus delegatensis R.T.Baker. The community also contains two acacia species as sub-dominants: A. dealbata and Acacia melanoxylon R.Br. The understorey species included Bedfordia salicina D.C., Coprosma quadrifida (Labill.) B.L.Rob., Pittosporum bicolor Hook., and Pomaderris apetala Labill. The site is predominately covered by grey-brown podzolic soils on mudstone, classified as Kurosol under the Australian Soil Classification system [24]. Kurosol soil is known as being acidic and nutrient poor [25] with vegetation structure strongly dependent on rainfall [24]. The climate has warm, dry summers and cool, moist winters, with a mean annual precipitation of $720 \mathrm{~mm}$ and a mean annual temperature of $17.5^{\circ} \mathrm{C}$. We used the basal area of trees per unit area as a proxy for long-term integrated 'productivity' ( $>$ four decades of canopy-tree-biomass accumulation). The forest stand is even-aged, being a natural regeneration following a 1967 stand-replacing fire. The few trees that had obviously lived through the fire (e.g., diameter at breast height $>100 \mathrm{~cm}$ were avoided during field measurements or excluded from analysis). For this study, we were interested in local heterogeneity across space, rather than temporal comparisons across different site histories. Landscape features were homogeneous across sites (e.g., little variation in topography, canopy, understory, and rock cover). 


\subsection{Site Selection and Survey Technique}

To collect data on community structure and to examine the relationship between tree size and total basal area we surveyed 24 sites using a modified point-quarter method [26], where each site was chosen using a random bearing and distance greater than $50 \mathrm{~m}$ from a randomly selected starting point located within the forest (Table S2). The tree closest in proximity to this distance and bearing was designated the starting tree. Each starting tree was identified to species level, and diameter at breast height (DBH in $\mathrm{cm}$ ) was measured. From the starting tree, the nearest neighbour in each of four compass-bearing quadrants (northeast, northwest, southeast and southwest) was selected. These four trees were also identified to species level and their DBH was also measured, with distance from the starting tree determined using a laser meter. This nearest-neighbour selection method was repeated for each of the four initial trees, giving a total of 17 trees (including the starting tree) at each of the 24 sites.

\subsection{Soil Sampling and Processing}

Soil samples were collected during early autumn from within the study community. Nine of the 24 sites were selected to represent variation in the proportion of Acacia (nitrogen fixers) present, relative to total basal area of all trees (Table S1). At each of these Acacia sites, five sampling locations were selected using a random bearing (in NW, SE, SW, NE directions) and a random distance from the starting tree. Five soil cores $(2 \times 15 \mathrm{~cm})$ were randomly placed in a $2 \times 2 \mathrm{~m}$ quadrant within each location for a total of 25 soil core samples per site. A site's soil samples were then mixed and homogenised by passing through a $2 \mathrm{~mm}$ sieve, which removed large roots, litter, and rocks. To determine relative soil water content, a $10 \mathrm{~g}$ subsample from each site was dried in an oven at $110^{\circ} \mathrm{C}$ for $48 \mathrm{~h}$. A $5 \mathrm{~g}$ soil subsample from each site was also ground in a ball mill (MM200 Mixer Mill, Retsch GmbH, Haan, Germany) for total C and N determination via a controlled combustion process in a PerkinElmer 2400 Series II Elemental Analyser (PerkinElmer, Australia [27]).

\subsection{Assessing Field Nutrient Availability}

To determine nutrient availability in the forest community, a $10 \mathrm{~g}$ subsample of each sieved soil sample was extracted with $40 \mathrm{~mL}$ of $2 \mathrm{M} \mathrm{KCl}$ to determine available $\mathrm{NH}_{4}{ }^{+}$and $\mathrm{NO}_{3}{ }^{-}$concentrations (Table S3). The tubes containing the soil and solution were shaken for $1 \mathrm{~h}$, then centrifuged for $3 \mathrm{~min}$ at $4000 \mathrm{rpm}$. A total of $10 \mathrm{~mL}$ of supernatant was removed with a syringe and filtered through a Whatman No. 42, $2 \mu \mathrm{m}$ syringe filter. The filtered extracts were analysed for $\mathrm{NH}_{4}{ }^{+}$and $\mathrm{NO}_{3}{ }^{-}$concentrations in a SmartChem Discrete Analyser (Westco Scientific Instruments, Brookfield, CT, USA). Additionally, a portion of the soil was also assessed to determine phosphorus $(\mathrm{P})$ concentrations in the soil at each site using the extraction methods described in [28]: $2 \mathrm{~g}$ of soil was mixed with $40 \mathrm{~mL} 0.005 \mathrm{M} \mathrm{NaCl}_{2}$ solution and shaken for $17 \mathrm{~h}$, then the mixed solution was extracted and analysed using the syringe method described above, with available P concentration determined using a SmartChem Discrete Analyser.

\subsection{Determining Nitrogen Mineralisation Rate}

The $\mathrm{N}$ mineralisation rate of the soil from each of the nine subsampled sites was determined using published protocols [29]. Briefly, $20 \mathrm{~g}$ of fresh soil from each composite sample was incubated in a sealed $500 \mathrm{~mL}$ glass jar placed in a darkened incubator at $25^{\circ} \mathrm{C}$ for 34 days. Jars were ventilated regularly to prevent soils becoming anoxic. Net $\mathrm{N}$ mineralisation, nitrification, and ammonification were calculated as the difference between initial total available $\mathrm{N}, \mathrm{NO}_{3}{ }^{-}$, and $\mathrm{NH}_{4}{ }^{+}$concentrations and those measured following the incubation period (Table S4). The rates of nitrogen mineralisation ( $\mathrm{mg} \mathrm{N} \mathrm{g}^{-1}$ soil) in relation to the proportion of $A$. dealbata in the community was analysed from incubation measurements from soil taken from nine sites, as the sum of $\mathrm{NH}_{4}{ }^{+}$and $\mathrm{NO}_{3}{ }^{-}$. Each of the nine sites had a different proportion of $A$. dealbata, and this natural cross-site variation was used to determine whether: (a) There were local-scale differences between nitrogen mineralisation rates and (b) there was a relationship between the proportion of $A$. dealbata and mineralisation rates of nitrogen. 
Results were analysed with a linear regression, using the resampling technique described below in Section 2.6.

\subsection{Statistical Methods}

All statistical analyses were done in Program R v3.3.2 (R Core Development Team 2016, Vienna, Austria). A likelihood-based generalised linear modelling framework was used to assess experimental predictors and dependencies. For each data set, an a priori model set was created, and strength of support was evaluated by using Akaike's information criterion, adjusted for small sample sizes $\left(\mathrm{AIC}_{c}\right)$. Model weights were calculated using the MuMIn package [30]. Akaike weights $\left(w_{i}\right)$ were used to assess model support; these represent the relative likelihood of a given model compared to others in the evaluation set (which can be of varying complexity and non-nested), by adjusting the likelihood for bias associated with fitting the parameters [31,32]. The relative support from the data for competing models was evaluated using the evidence ratio (ER), the ratio of the respective model's $w_{i}$. The percentage deviance (\%DE) explained by each model relative to the null (intercept only) was used to assess structural goodness of fit.

In cases where multiple measurements of the dependent variable were taken at each level of a predictor (see Section 3.4), resampling was used (with one outcome selected randomly for any given predictor level and repeated 10,000 times) to avoid pseudoreplication, with the models fitted repeatedly to each subsample. The median prediction from the set of models fitted to the resampled data was used to determine the slope of the predictor and 95\% confidence intervals. As a check, these were also compared to models fitted to the medians of the raw data (i.e., ignoring within-sample heterogeneity).

The 24 plots were analysed to assess the influence of Acacia sp. on Eucalyptus sp., and total site productivity. In this case, the a priori models represented additive combinations of the following predictors (of varying complexity): Proportion of $A$. dealbata biomass, the average size of $A$. dealbata, the number of species, or the variance of the pairwise distances between trees. Dependent variables were total basal area of a site or, alternatively, the average size of the eucalypts (DBH cm).

To test whether the availability of soil nutrients ( $\mathrm{C}$ and $\mathrm{N}$ ) had an influence on the average size of eucalypts or the total basal area (see Section 3.3), fitted linear models were restricted to either one or two terms due to sample-size limitations (nine total sites). Average size of A. dealbata was determined to be the most important factor influencing site productivity during the 24-plot analysis (Section 3.1 and see Results), and therefore was included as a control term in all a priori models. The other predictor variable assessed was either: $\mathrm{C}, \mathrm{N}$, or pre-total mineralisation of N. Phosphorus was also considered but there were negligible differences across sites.

\subsection{Laboratory Litter Experiment}

The impact of litter quality and quantity on decomposition rate was determined experimentally by manipulating the relative contribution of litter from the three co-occurring species in the field sites (E. obliqua, A. dealbata, and P. apetala). Newly senesced leaves of the three tree species were collected from each of the 24 sites. The leaf litter was combined to give a representative sample of each of the three species across the entire field site and subsequently dried in an oven at $110^{\circ} \mathrm{C}$ for $24 \mathrm{~h}$. Leaves were shredded in an adapted coffee grinder and then ground to powder in a ball mill (MM200 Mixer Mill, Retsch, Haan Germany).

We developed seven treatments ranging from $100 \%$ contribution of a single species to equal proportions (i.e., an even mixture; Table 1). The total weight of litter was controlled at $2 \mathrm{~g}$, with $10 \%$ of the total weight as sieved pasteurised sand $(20 \mathrm{~g})$, which eliminated the effect of existing soil organic matter interfering with the effect of litter amendment on the incubations. Three replicates were prepared for each treatment, each with a different dominant species contributing the largest percentage of litter to the mix, yielding a total of 63 replicates, with three 'no litter' controls. Litter was apportioned into appropriate weights based on the percentage contribution of the species (from $0 \%$ to $100 \%$ contribution: Table 1) and placed in a $60 \mathrm{~mL}$ specimen container in a $500 \mathrm{~mL}$ glass jar containing 
the pasteurised sand. A $2 \mathrm{~mL}$ soil slurry solution was added to each jar, being prepared by mixing $50 \mathrm{~g}$ (fresh weight) of soil taken from the study site (Section 2.1), with $100 \mathrm{~mL}$ of deionised water. The soil was added to the incubation containers with a minimum of additional soil organic matter such that there was a consistency across each treatment. Additionally, samples were supplemented with $2.6 \mathrm{~mL}$ of deionised water to bring them to $60 \%$ field capacity, which is within the range of soil water content $(50 \%-70 \%)$ that has been shown to encourage optimal microbial activity [33]. Field capacity was determined by flooding a $3 \mathrm{~g}$ subsample of soil and allowing it to stand for $30 \mathrm{~min}$ before draining the free water on a porous ceramic plate and then weighing to obtain water content at field capacity [34]. The subsample was then oven-dried for $24 \mathrm{~h}$ at $105{ }^{\circ} \mathrm{C}$ to obtain soil dry weight. To control for the respiration rate of the organic matter present in the soil slurry, inoculum blanks consisting of sand and the soil slurry (but no added litter) were also prepared. The sealed jars were incubated in the dark at $25^{\circ} \mathrm{C}$. Gas samples were obtained after $1,2,4,7,10,14,18,23,30$, and 35 days of incubation.

Table 1. Relative proportion of litter across the seven treatments (ranging from an even mixture of 1, to one dominated by a single species (0). The three species (Eucalyptus obliqua L'Hér, Acacia dealbata Link, and Bedfordia salicina D.C.) are the most common found across the site.

\begin{tabular}{cccc}
\hline Evenness & E. obliqua & A. dealbata & B. salicina \\
\hline \multirow{2}{*}{0} & $100 \%$ & $0 \%$ & $0 \%$ \\
& $0 \%$ & $100 \%$ & $0 \%$ \\
0.2 & $0 \%$ & $0 \%$ & $100 \%$ \\
\hline \multirow{4}{*}{0.4} & $95 \%$ & $2.5 \%$ & $2.5 \%$ \\
& $2.5 \%$ & $95 \%$ & $2.5 \%$ \\
& $2.5 \%$ & $2.5 \%$ & $95 \%$ \\
\hline \multirow{3}{*}{0.6} & $88 \%$ & $6 \%$ & $6 \%$ \\
& $6 \%$ & $88 \%$ & $6 \%$ \\
& $6 \%$ & $6 \%$ & $88 \%$ \\
\hline \multirow{2}{*}{0.8} & $79 \%$ & $10.5 \%$ & $10.5 \%$ \\
& $10.5 \%$ & $79 \%$ & $10.5 \%$ \\
& $10.5 \%$ & $10.5 \%$ & $79 \%$ \\
\hline \multirow{2}{*}{0.9} & $65 \%$ & $17.5 \%$ & $17.5 \%$ \\
& $17.5 \%$ & $65 \%$ & $17.5 \%$ \\
& $17.5 \%$ & $17.5 \%$ & $65 \%$ \\
\hline \multirow{2}{*}{1} & $55 \%$ & $22.5 \%$ & $22.5 \%$ \\
& $22.5 \%$ & $55 \%$ & $22.5 \%$ \\
& $22.5 \%$ & $22.5 \%$ & $55 \%$ \\
\hline & $33.3 \%$ & $33.3 \%$ & $33.3 \%$ \\
& $33.3 \%$ & $33.3 \%$ & $33.3 \%$ \\
& $33.3 \%$ & $33.3 \%$ & $33.3 \%$ \\
\hline
\end{tabular}

Daily C mineralisation results for the litter experiment were analysed to determine the amount of potentially mineralisable C using a nonlinear differential model (two-pool model with one pool constant), as follows:

$$
\frac{d C}{d t}=C_{a} \cdot k_{a} e^{\left(-k_{a t}\right)}+r
$$

where $\frac{d C}{d t}$ is the cumulative amount of $C$ mineralised at time $t$ (per day in this case), $C_{a}$ is the amount of $\mathrm{C}$ in the fast or labile $\mathrm{C}$ pool, $k_{a t}$ is the respiration rate constant of $\mathrm{CO}_{2}$ evolution from the active pool, and $r$ is the non-labile soil $C$ respiration rate, which is effectively a constant over timescales less than a year (e.g., [33]). We assumed the labile $\mathrm{C}$ pool to have come directly from recent plant inputs (e.g., labile $\mathrm{C}$ compounds in litter [35]). Decomposition rates were corrected for $\mathrm{CO}_{2}$ release from the inoculum by subtracting the daily mean $\mathrm{CO}_{2}$ release of inoculum blanks from each experimental unit. 
We then explored the differences in the rate of decomposition of the labile carbon per day and the proportion of Acacia in the litter over time. A linear regression was fitted to the resampled nitrogen composition taken at each proportion of $A$. dealbata (see next section). To determine the differences in carbon mineralisation of litter over time, each of three species: E. obliqua, A. dealbata, and Bedfordia sp. were measured for cumulative $\mathrm{CO}_{2}$ evolution during litter incubation over a 40 day period and analysed using the Michaelis-Menten equation (a three-term nonlinear saturating model). Although the Michaelis-Menten equation (MME) is commonly used as a simple representation of enzyme kinetics, it can also serve as a useful two-parameter characterisation of any system that exhibits some type of reaction velocity with a non-linear saturation (via estimation of a maximal rate and half-saturation parameter, with a start at the origin). We agree that soils, being complex mixtures, are unlikely to follow any single, simple reaction dynamics. We instead assume that the overall response will be MME-like but fit the model as a phenomenological rather than overtly mechanistic descriptor of the aggregate system response. The fact that it fits extremely well (See results, $R^{2}$ ranging from $90 \%-94 \%$ ) gives confidence in this approach.

\section{Results}

\subsection{Relationship between Size of Trees and Total Basal Area across All 24 Plots}

The average size of $A$. dealbata (biomass) was the best predictor for total basal area across the 24 plots $\left(d f=3, w \mathrm{AIC}_{c}=0.32\right)$, explaining $12 \%$ of the total deviance. There was little information-theoretic support for the saturated model (containing all three variables), nor for the two predictor variables (i) variance of distances between trees $\left(d f=3, w \mathrm{AIC}_{c}=0.13\right)$ and (ii) proportion of $A$. dealbata (biomass) $\left(d f=3, w \mathrm{AIC}_{c}=0.10\right)$; these were no better supported than the null expectation. Average tree size of $A$. dealbata (biomass) in additive combination with the variance of distances between trees was the best model for predicting average size of eucalypts $\left(d f=4, w \mathrm{AIC}_{c}=0.46, \% \mathrm{DE}=29.1\right)$, followed by the saturated model $\left(d f=5, w \mathrm{AIC}_{c}=0.35, \% \mathrm{DE}=36.5\right)$. A post hoc analysis suggested that of the two best predictors for average size of eucalypts, variance of distances between trees was 1.6 times better supported than the average size of $A$. dealbata (biomass). See Supplementary Materials for all raw data associated with the linear models and associated analyses.

\subsection{Local Soil Nutrient Availability}

There was a positive relationship between soil mineral $\mathrm{N}$ availability and soil $\mathrm{C}$ content (\%) $\left(R^{2}=0.51\right.$, slope $=1.680,95 \% \mathrm{CI}=0.4-2.90$; Figure $\left.1 \mathrm{a}\right)$, indicating that nitrogen availability was dependent upon the amount of organic matter in the soil. However, neither soil total $\mathrm{N}(\%)$ content nor available mineral nitrogen concentrations were related to the basal area of $A$. dealbata across the nine sites sampled $\left(R^{2}=0.03\right.$, slope $=-0.01,95 \% \mathrm{CI}=-0.03-0.02$ and $R^{2}=0.04$, slope $=-0.29,95 \% \mathrm{CI}$ $=-1.40-0.81$, respectively; Figure 1). Conversely, A. dealbata average size did show a strong negative relationship to soil mineral $\mathrm{N}$ availability $\left(R^{2}=0.47\right.$, slope $\left.=-0.61,95 \% \mathrm{CI}=-1.10-0.12\right)$, but not to soil $\mathrm{N}$ content $(\%)\left(R^{2}=0.19\right.$, slope $\left.=-0.01,95 \% \mathrm{CI}=-0.03-0.01\right)$. This result shows that none of the predictors for nutrient availability in the soil were predictive of total basal area of $A$. dealbata. 
(a)

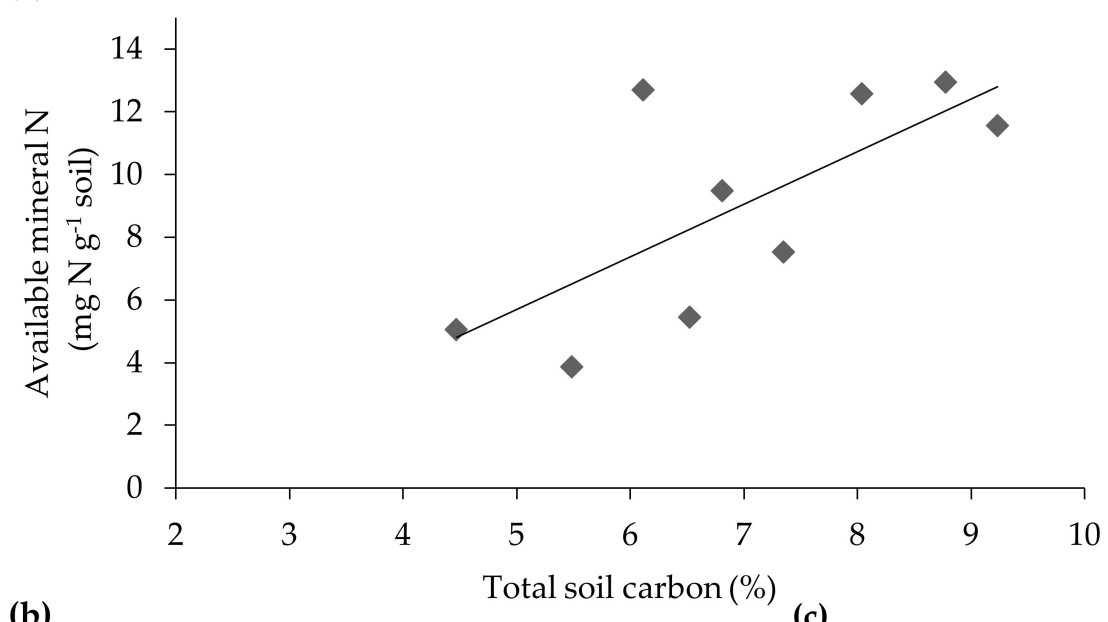

(b)

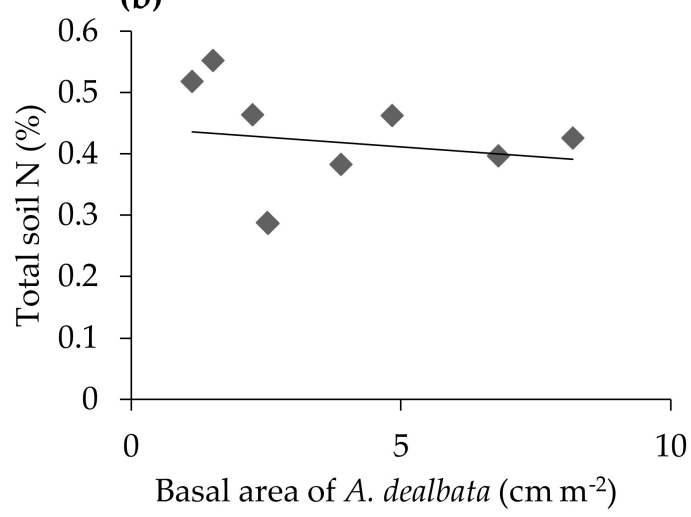

(c)

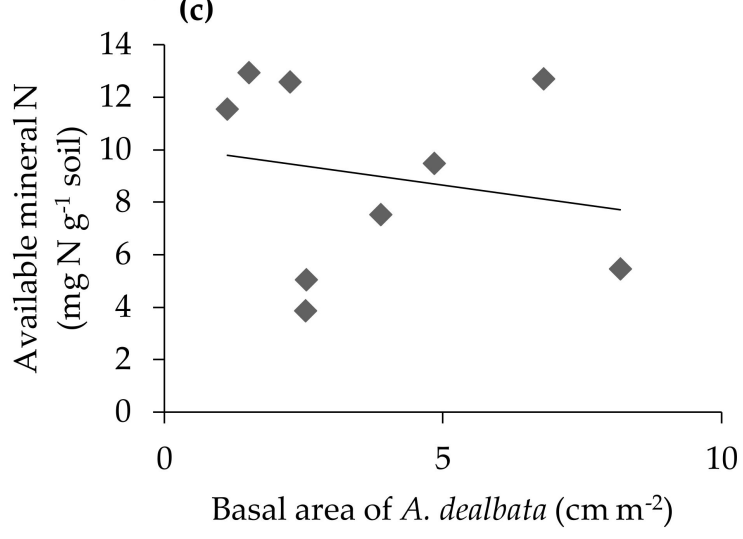

Figure 1. Relationship between total basal area of $A$. dealbata and the amount of nitrogen at each soil site in two different forms: (a) Relationship between total soil carbon (\%) and available mineral nitrogen (N). Concentrations are determined from soil collected from each of the nine sites in a eucalypt forest. (b) Total soil organic matter quantity in terms of total soil nitrogen (\%) and the total basal area at each soil site and (c) Available mineral N present at each site and the relationship to total basal area of A. dealbata.

\subsection{Local $C$ and N Dynamics}

Since $C$ mineralisation is an enzymatic process, its rate is dependent upon the availability of substrate; as expected, there was a clear relationship in our analysis between $C$ mineralisation rate and soil organic matter content, whether expressed as total soil C or N $\left(R^{2}=0.47\right.$, slope $=1371, \mathrm{CI} \%=$ $275-2467$ and $R^{2}=0.65$, slope $=96.0$, CI $\%=42.4-149.6$, Figure 2). Thus, the rate of soil organic matter decomposition was dependent upon the quantity of organic matter present. 
(a)

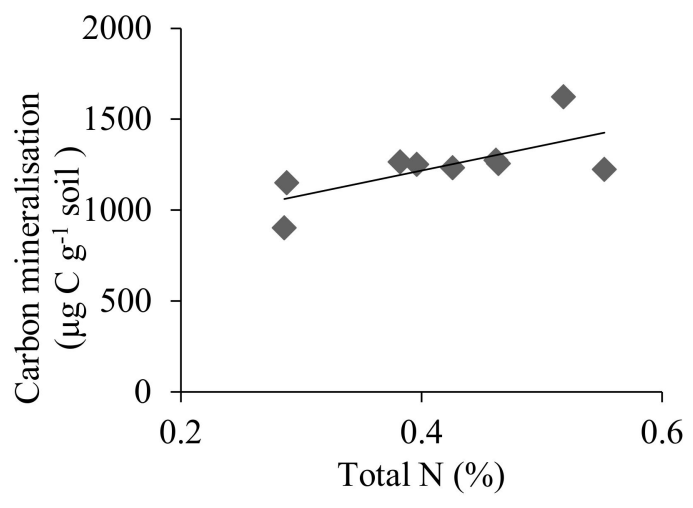

(b)

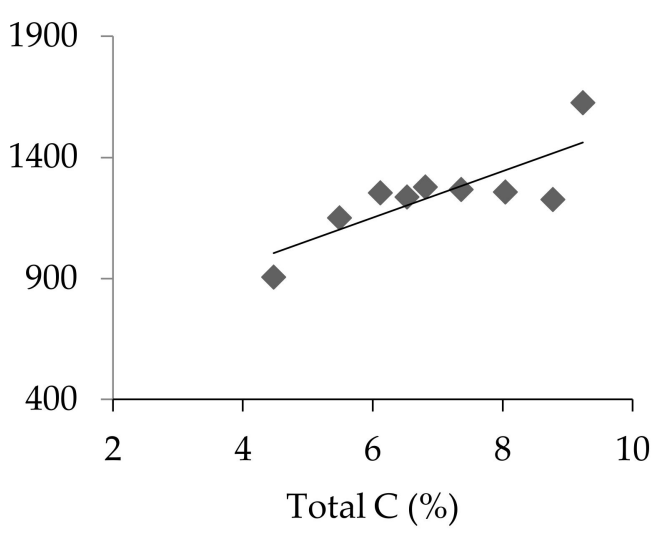

Figure 2. Relationship between total carbon mineralised ( $\mu \mathrm{g} \mathrm{C} \mathrm{g}^{-1}$ soil) and organic matter quality demonstrated as two different forms. (a) Total soil nitrogen ( $\mathrm{N} \%) R^{2}=0.47$ and (b) total soil carbon $(\mathrm{C} \%) R^{2}=0.65$. Data were determined from soil collected at nine different sites in a eucalypt forest.

There was a strong positive correlation between field-mineral-N availability and measured nitrification rate in the laboratory $(r=0.79)$. Therefore, the measurement of soil nitrogen availability of field samples corresponded well with measured rates of nitrogen transformation. There was also a strong relationship between rates of $\mathrm{N}$ transformation, ammonification, and nitrification $(r=0.64)$, demonstrating that the rate of nitrification was dependent on the rate of net ammonification, and vice versa.

However, there was only a weak correlation between nitrification and total $\mathrm{N}$ mineralisation $(r=0.33)$. Indeed, nitrification rates were relatively stable across the range of sites in comparison to the wide range of ammonification rates (Figure 3). There was by contrast, a strong positive relationship between net ammonification and net $\mathrm{N}$ mineralisation rates $(r=0.94$, Figure 3$)$, indicating that the supply of mineral $\mathrm{N}$ in this system was related to the conversion of organic $\mathrm{N}$ to ammonium.

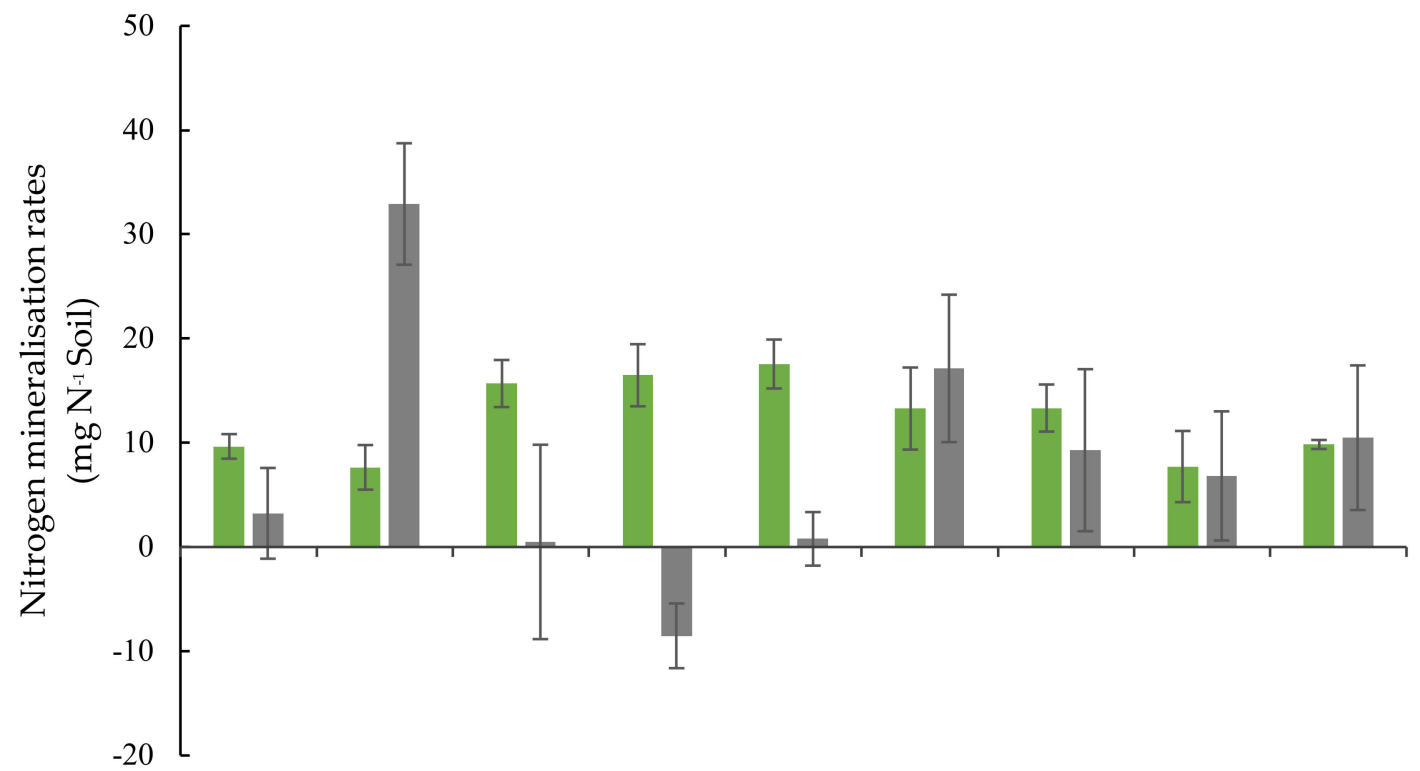

Sites (A to I)

(a)

Figure 3. Cont. 


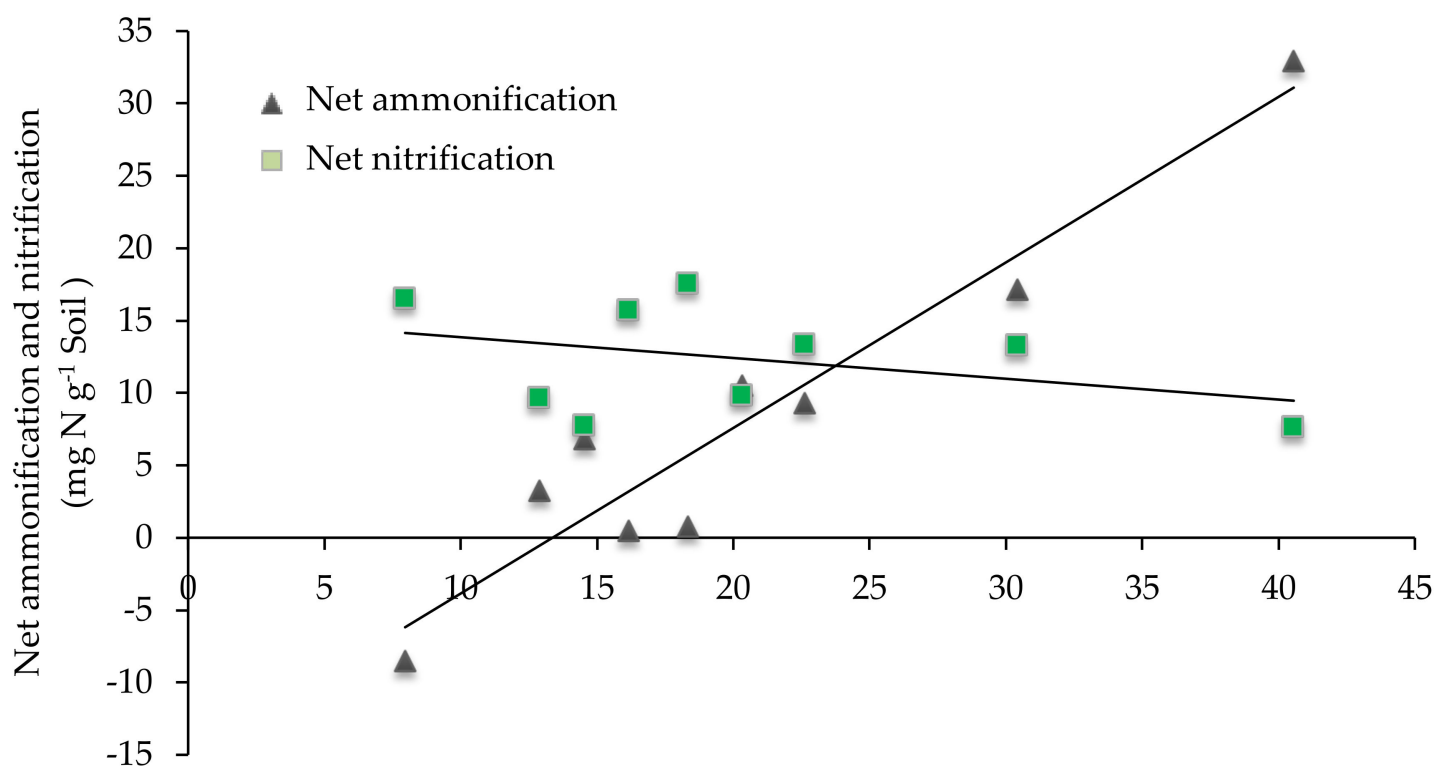

Net $\mathrm{N}$ Mineralisation (mg $\mathrm{N} \mathrm{g}^{-1}$ Soil )

(b)

Figure 3. Rates of nitrogen $(\mathrm{N})$ transformation obtained from incubation measurements from soil taken from nine sites. (a) Rates of ammonification $\left(\mathrm{mg} \mathrm{N} \mathrm{g}^{-1}\right.$ soil); as the conversion of $\mathrm{C}$ and $\mathrm{N}$ (\%) into $\mathrm{NH}_{4}^{+}$; and the rates of nitrification (mg N g${ }^{-1}$ soil); as the conversion of $\mathrm{NH}_{4}{ }^{+}$into $\mathrm{NO}_{3}{ }^{-}$. One standard error (+ and - ) is shown for each site measurement. (b) Relationship between net $\mathrm{N}$ mineralisation rates and net ammonification and net nitrification rates from soil collected from the nine sites.

\subsection{Relationship between Litter Quality, Quantity, and Litter Decomposition}

Field samples from communities with $A$. dealbata had almost three times more nitrogen in the litter $(2.57 \% \pm 0.11 \%)$ compared to E. obliqua $(0.53 \% \pm 0.03 \%)$ and Bedfordia sp. $(0.80 \% \pm 0.05 \%)$, and thus a lower $\mathrm{C}: \mathrm{N}$ ratio. A higher proportion of $A$. dealbata in the litter (\%) subsequently led to a higher release of labile carbon during the litter-decomposition experiment (Table 2; Figure 4). Both approaches to fitting this relationship statistically: (i) The median of the resampled points and (ii) the initial linear model to the median points, yielded nearly identical $R^{2}$ (indicating a negligible effect of pseudoreplication).

Table 2. Litter decomposition table showing the intercept, slope, and corresponding $95 \%$ confidence intervals for each, the initial model (fitted to the raw data) and the median of model fits to resampled data points; goodness of fit is indicated by the $R^{2}$.

\begin{tabular}{ccccccc}
\hline Model (Median) & Intercept $(\boldsymbol{\alpha})$ & $\mathbf{9 5 \%} \mathbf{C I}$ & Slope $(\boldsymbol{\beta})$ & $\mathbf{9 5 \%} \mathbf{C I}$ & Sigma & $\boldsymbol{R}^{\mathbf{2} \%}$ \\
\hline Initial & 2838 & $1818-3859$ & 177 & $155-199$ & 2829 & 81.8 \\
Resampled & 2877 & $290-5509$ & 169 & $36-267$ & 2192 & 81.7 \\
\hline
\end{tabular}




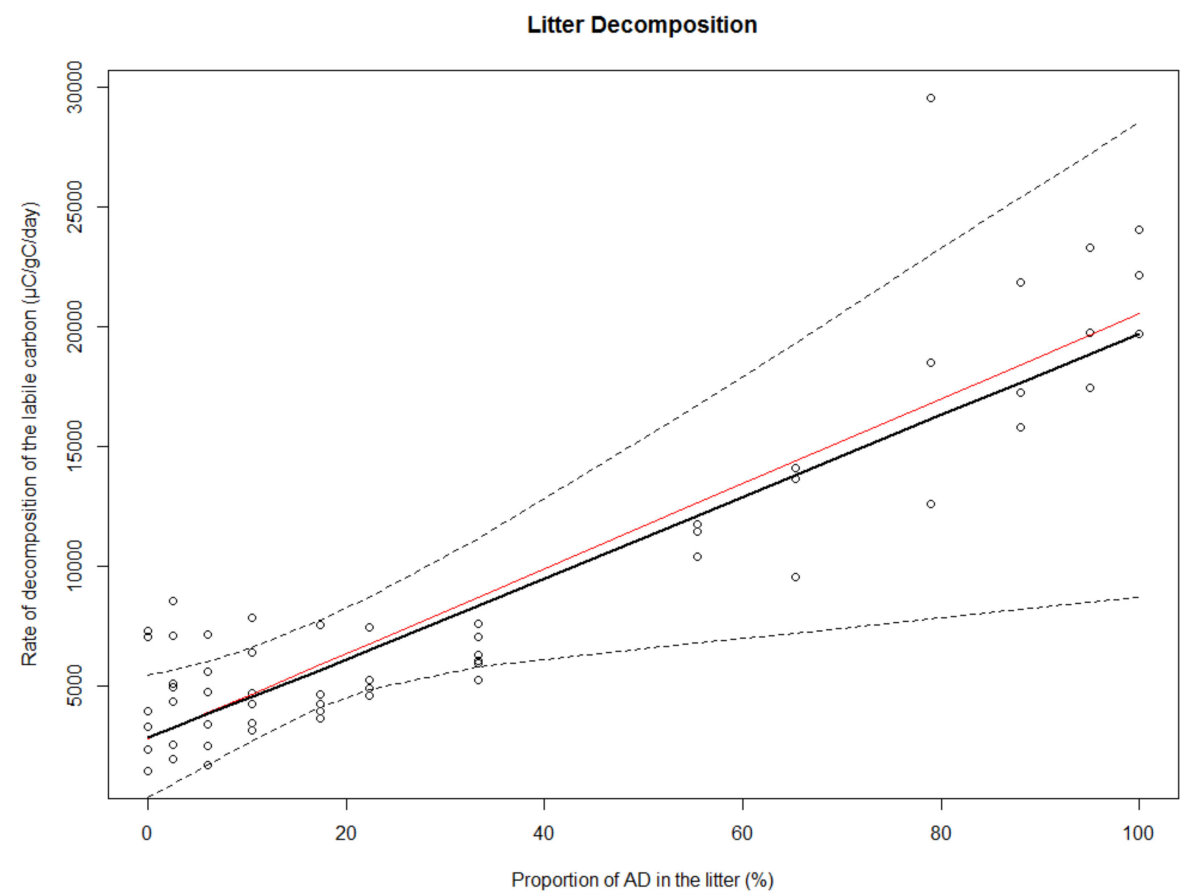

Figure 4. The relationship between the rate of labile carbon decomposition and of the nitrogen fixed $A$. dealbata in the litter. The red line represents the initial linear regression model to the median points $\left(R^{2}: 81.8 \%\right)$, and the black line shows the median of the resampled points $\left(R^{2}: 81.7 \%\right)$. Dotted lines represent the confidence bounds for the resampled data.

The resampled fits of the Michaelis-Menten saturating equation (MM) for the cumulative $\mathrm{CO}_{2}$ evolved from the decomposition of the litter was similar for each of the three species (Table 3; Figure 5). Although both median and resampled fits yielded a similar $R^{2}$, the resampled model did reveal subtle deviations in the data, but had little to no influence on the $R^{2}$, with $A$. dealbata showing the largest variation of $R^{2}$ between models (1.9\% difference). A. dealbata had the lowest half-saturation point for the cumulative carbon mineralisation, reaching it faster than E. obliqua and Bedfordia. However, all species released a comparable total amount of $\mathrm{CO}_{2}$ per gram of litter, as indicated by the similar asymptotes of the MM equation (Table 3). 
Table 3. The model fit $\left(R^{2}\right)$ for each species for the cumulative $\mathrm{CO}_{2}$ evolved from the decomposition of the litter: Initial Michaelis-Menten equation fit to the median data points, and the resampled data (median model prediction). Shown is the asymptote $(\alpha)$, half saturation point ( $\beta$ ), and corresponding $95 \%$ confidence intervals, for each species.

\begin{tabular}{|c|c|c|c|c|c|c|}
\hline Model (Median) & Asymptote $(\alpha)$ & $95 \% \mathrm{CI}$ & Half Saturation Point $(\beta)$ & $95 \% \mathrm{CI}$ & Sigma & $R^{2}(\%)$ \\
\hline \multicolumn{7}{|c|}{ Eucalyptus obliqua } \\
\hline Initial & 92,189 & $84,612-101,407$ & 9.9 & $7.8-12.7$ & 2210 & 93.3 \\
\hline Resampled & 90,526 & $72,756-116,217$ & 9.8 & $5.7-18.0$ & 8355 & 93.7 \\
\hline \multicolumn{7}{|c|}{ Acacia dealbata } \\
\hline Initial & 89,561 & $81,141-100,055$ & 5.6 & $3.9-8.0$ & 3769 & 90.9 \\
\hline Resampled & 89,563 & $74,410-105,699$ & 5.7 & $3.5-9.1$ & 6729 & 92.8 \\
\hline \multicolumn{7}{|c|}{ Bedfordia sp. } \\
\hline Initial & 92,476 & $76,899-117,482$ & 10.1 & $5.8-18.0$ & 4637 & 89.1 \\
\hline Resampled & 84,947 & $67,487-113,376$ & 7.9 & $4.4-7.9$ & 8859 & 90.2 \\
\hline
\end{tabular}


a) Eucalyptus obliqua

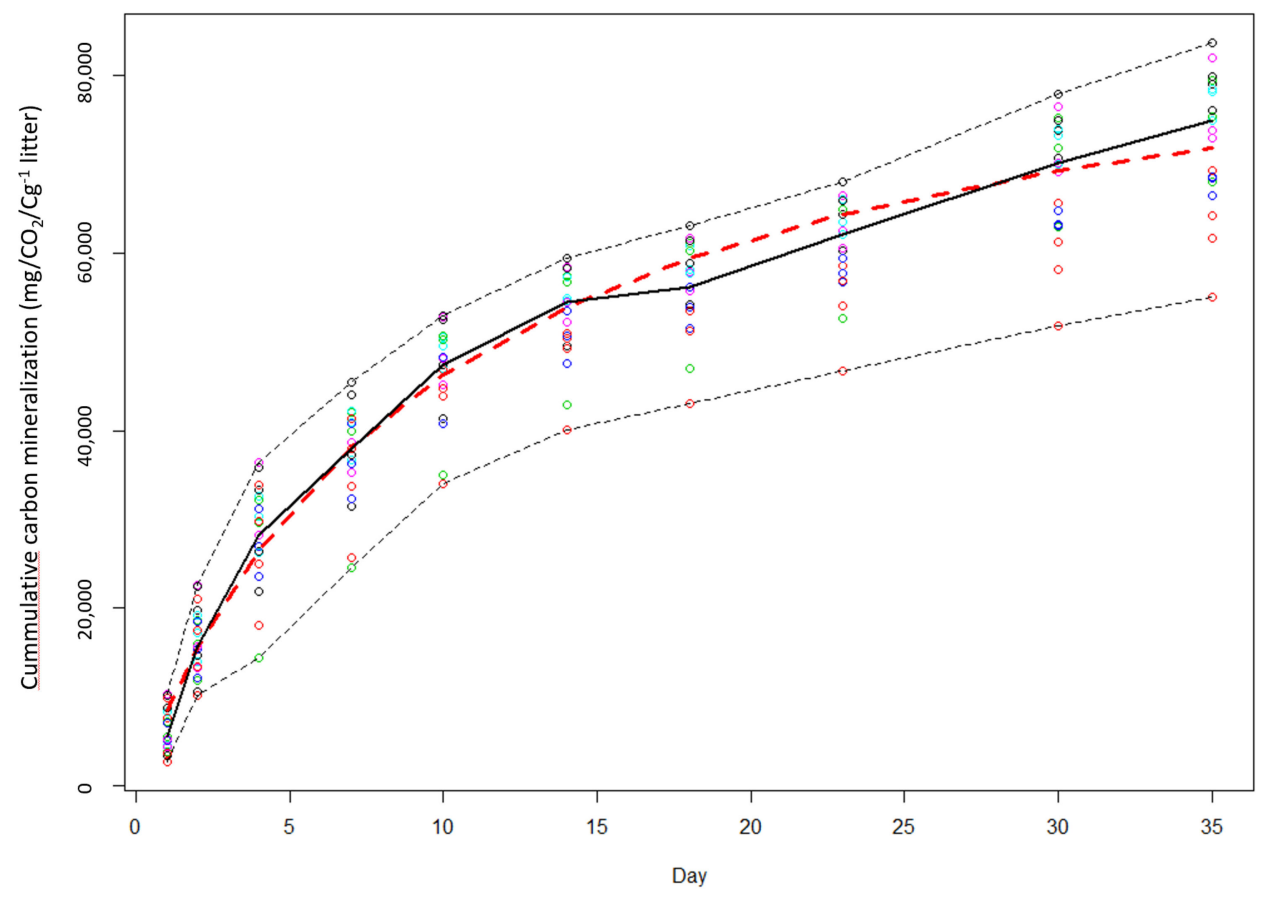

b) Acacia dealbata

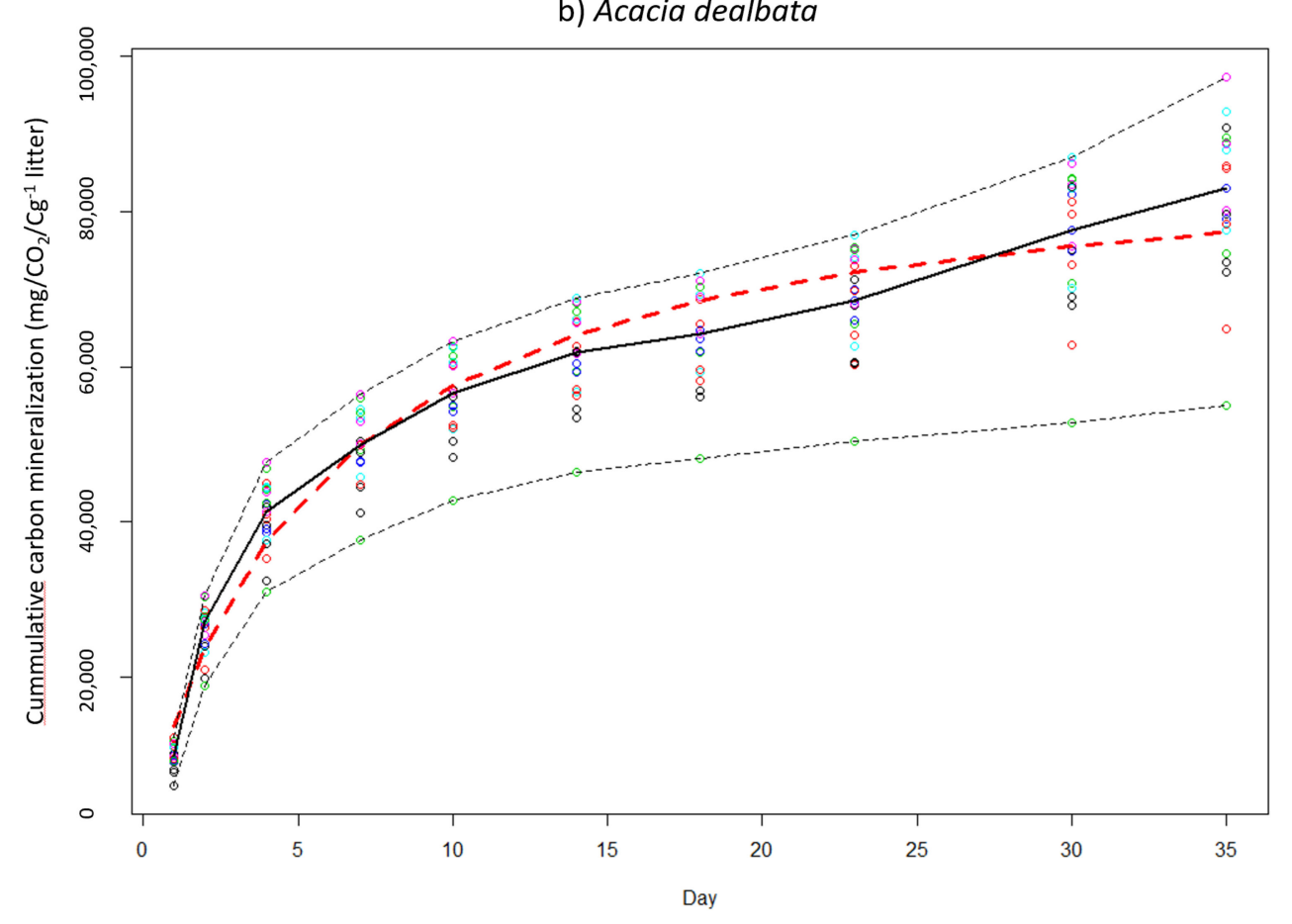

Figure 5. Cont. 
c) Bedfordia salicina

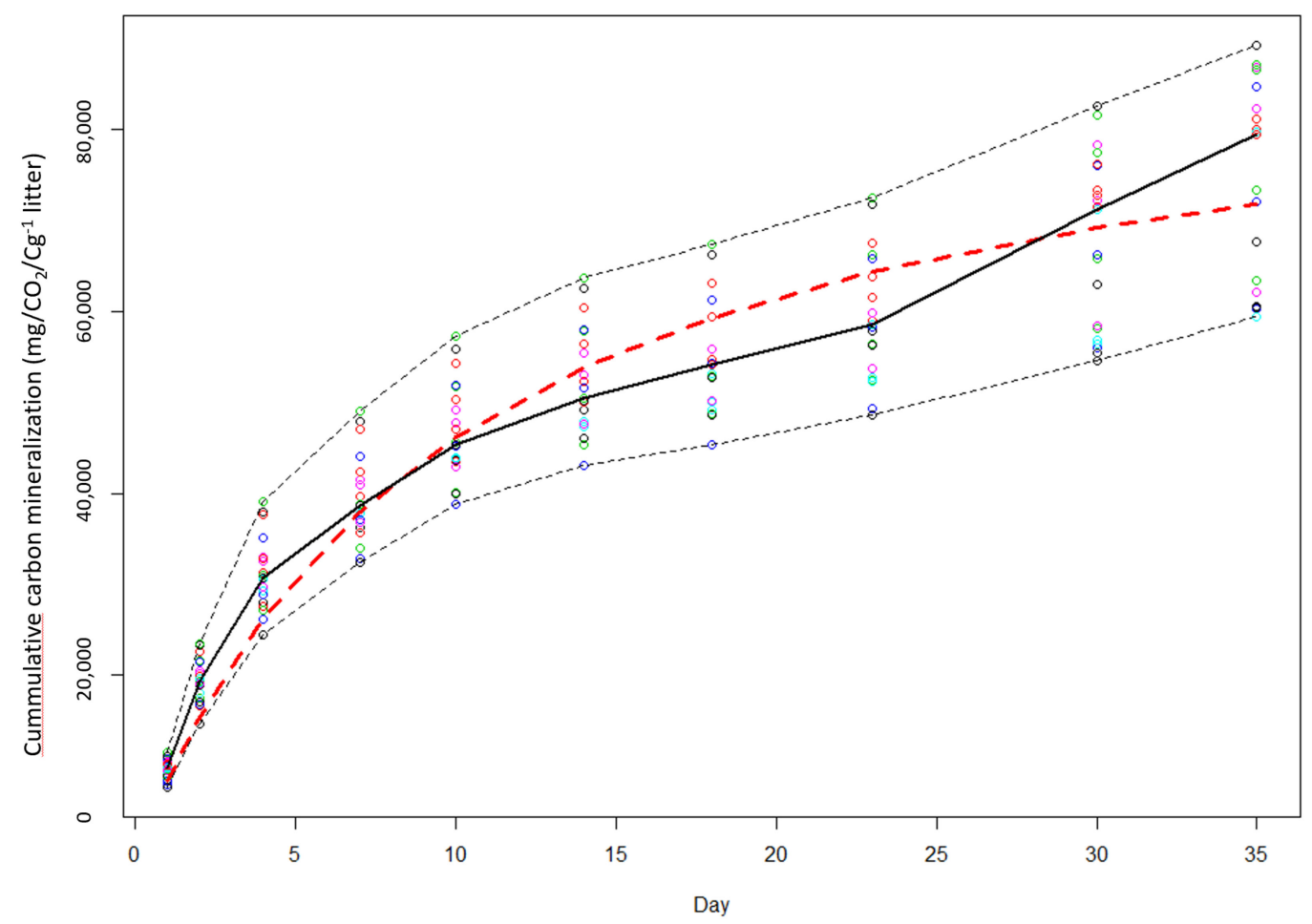

Bedfordia sp. (c)

Figure 5. Cumulative carbon mineralisation rate over time (40 days) against all data points for each species. The red dotted line represents the Michaelis-Menten equation (MM) fit to the median data points. The black line is the median of the resampled data fits using the MM equation, with corresponding black dotted 95\% confidence bounds: (a) E. obliqua initial MM fit $\left(R^{2}: 93.3\right)$ and resampled median $\left(R^{2}\right.$ : 93.7\%); (b) A. dealbata initial MM fit $\left(R^{2}: 90.9 \%\right)$ and resampled median $\left(R^{2}: 92.8 \%\right)$; (c) Bedfordia sp. initial MM fit $\left(R^{2}: 89.1 \%\right)$ and resampled median $\left(R^{2}: 90.2 \%\right)$.

\section{Discussion}

We have shown that experimental mixtures of plant species from Australian eucalypt forests that contain a higher proportion of nitrogen-fixing A. dealbata litter have higher decomposition rates (Figures 4 and 5). This was driven primarily by the three-fold increase in nitrogen $(\mathrm{N})$ content in A. dealbata litter compared to, for example, B. salicina (another understorey tree) and the canopy-forming E. obliqua. This result is supported mechanistically by previous studies (e.g., [36,37]) showing that decomposition rates of litter mixtures are driven predominantly by substrate quality, particularly the amount of $\mathrm{C}$ and $\mathrm{N}$ in the litter mixtures. Plant functional traits, such as nitrogen fixation, are key drivers of higher-quality substrates in forest ecosystems, with the potential to mediate and control plant abundance, biomass, and composition via inherent differences between species in quality (C:N, lignin: $\mathrm{N})$ and quantity $(\% \mathrm{C}, \% \mathrm{~N})$ of plant litter [38]. Indeed, the quantity of carbon (C) in the soil at our Tasmanian forest sites was the best predictor of average eucalypt tree size, followed by the average size of $A$. dealbata (Figure 1). Studies that have examined this phenomenon in other forests have demonstrated that the identity and functional traits of litter-creating species can surpass species diversity as the main driver of decomposition [39-42].

Given that $A$. dealbata presence and abundance indirectly controls litter decomposition via nitrogen availability and was consequently a useful predictor of average E. obliqua tree size, this research supports the hypothesis that $\mathrm{N}$ availability and cycling would be higher in sites with a greater $A$. dealbata biomass. Our results align with those of [23], who demonstrated that the presence of Acacia mearnsii (another $\mathrm{N}$-fixer) influenced the quantity and rates of $\mathrm{N}$ and $\mathrm{P}$ cycling in Eucalyptus globulus 
mixed forests compared to monocultures, in an 11-year experimental trial. Similar relationships have also been found in boreal forests, grasslands, and tropical forests, through field $\mathrm{N}$ fertilisation trials [42-44] and in laboratory experiments [45,46]. However, in our study, there was no observable relationship between $A$. dealbata biomass and the total amount of organic matter $(\mathrm{C}$ and $\mathrm{N})$ or the concentrations of $\mathrm{NH}_{4}{ }^{+}, \mathrm{NO}_{3}{ }^{-}$or with total mineral $\mathrm{N}$ and $\mathrm{P}$ in the soil, despite high heterogeneity among sites in $\mathrm{N}$ availability and cycling (Figure 3). Further, we found no correlation between total available soil-mineral $\mathrm{N}$ and average $A$. dealbata tree size. As $A$. dealbata was the sub-dominant canopy species in our forest system, and there was 30\% more biomass of $A$. dealbata relative to other sites, the potential for $\mathrm{N}$-rich soil from $\mathrm{N}$-fixers with high $\mathrm{N}$ litter should have been realised. As such, this null result demands an explanation.

There are several plausible reasons as to why a higher $\mathrm{N}$ content was not observed at sites with high $A$. dealbata biomass (Figure 1), with these inferences potentially useful for forest management during early succession and development. Two leading candidates are: (1) A. dealbata is a nitrogen fixer and therefore is not reliant on high soil $\mathrm{N}$ to grow, whereas this might be limiting for other species (such as E. obliqua); and (2) due to the relatively short lifespan of $A$. dealbata ( 40 years) compared to E. obliqua (>100 years) [47], a higher $N$ litter might have been present during the early stages of forest succession, when growth was faster and intraspecific competition more intense, but that early signal has since dissipated (e.g., [48,49]). The development of a forest is characterised by both changes in structure and succession, with concomitant consequences for productivity of standing forests and regrowth [50]. For example, restoration of forest ecosystems with multiple forest species helps rebuild multiple functions, such as species structure, litter composition, and soil nutrients of an area [9,51]. Selective logging of natural forests is a form of disturbance, and management plans require some older trees to be left in a logged area for animal habitat and seedling regeneration. Our results suggest that complimentary tree species, such as A. dealbata and E. obliqua, should be left in such areas, to maintain the overall functionality, especially during early successional development [52]. However, our experimental results only show that complementarity and nitrogen facilitation can occur, whereas determining this relationship explicitly within a natural setting (such as $[53,54]$ is challenging to demonstrate, especially in the face of inevitable inter-site heterogeneity).

In terms of confounding effects, there are also many factors that can influence environmental and topographic heterogeneity within eucalypt forests, which might act to mask any relationship and thus cause the field results to deviate from the expectations of the experimental incubations. For example, the realised distribution of $A$. dealbata litter at the field sites might be influenced by localised erosion or mineral dilution of litter and topographic variation, causing the build-up of litter in soil depressions or exclusions from mounds, but which were not reflected in controlled soil collections. The few studies that have examined patterns of litter fall dispersal and collection in field conditions support the notion of high heterogeneity in litter-sample collection, finding large disparities between the location of the litter source (local tree canopy) and the actual litterfall sample that was collected [55]. Similarly, [56] found that under-representation of certain components of vegetation, such as litter, can have important implications for the estimation of forest productivity and nutrient cycling, leading to a scale mismatch between sample points and the character of the soil across the forest.

While this study focussed in detail on $\mathrm{N}$ transformations and cycling within a Tasmanian eucalypt forest system, $\mathrm{N}$ losses could not be determined explicitly or assessed in the field. Leaching of $\mathrm{N}$ from the soil at field sites might contribute to the low $\mathrm{N}$ availability; this suggests that future studies should focus on determining how much $\mathrm{N}$ is below the $15 \mathrm{~cm}$ of topsoil that was collected in our sampling protocol. Stable isotope tracing is one method that could be used to track N pathways through the soil, providing information of $\mathrm{N}$ availability and movement at various depth stratifications. If leaching does occur, then it is likely that $\mathrm{N}$ will accumulate further down the soil profile. This effect might have been exacerbated by the overwhelming dominance of the deep-rooted E. obliqua (numerically and in terms of biomass), whose leaves, due to variations in litter characteristics between the two species such as litter size, mass, decomposability and chemical composition [57,58], dominate the surface litter 
composition, and yet it is able to access historically deposited nutrients that are now only found deep in the soil profile.

\section{Conclusions}

In conclusion, we have presented an experimental and field-observational snapshot of nutrient dynamics within a typical eucalypt forest community from southern Australia. We have demonstrated the importance of understanding litter decomposition, but also the need to quantify how different sources of $\mathrm{N}$ can impact $\mathrm{N}$ availability and cycling. Repeated sampling across a larger range of seasons in Tasmanian eucalypt forests (including wet and dry periods) would be important to provide a temporal component to a spatially complex process. Our results also highlight the difficulty in defining ecosystem processes and function using any single mechanism in forests-even one so apparently clear cut as $\mathrm{N}$ availability-because of the many processes that ultimately interact to determine the size of trees and relative abundance of species.

Supplementary Materials: The following are available online at http://www.mdpi.com/1999-4907/10/4/340/s1, Figure S1: Phosphorous content in the soil from the nine sites surveyed for soil samples, Table S1: Proportion of basal area (relative to the total basal area of each site) for each species present in the field 24 sites, Table S2: Summary statistics of key characteristics within each of the 24 field sites surveyed, Table S3: Data on soil nutrient availability from the soil samples taken from each of the subset of nine sites that were subject to soil profiling, Table S4: Data on soil nutrient mineralisation from the soil samples taken from each of the nine soil-sampling sites. Abbreviations given in the footnote.

Author Contributions: J.C.B. and M.J.H. conceived and designed the experiments; J.C.B. performed the experiments; B.W.B., J.C.B, and E.M.R. analysed the data; and all authors contributed to the manuscript drafts and writing and gave final approval for publication.

Funding: This work was funded by Australian Research Council grant FL160100101.

Conflicts of Interest: The authors declare no conflict of interest.

\section{References}

1. Becker, K.; Wulfmeyer, V.; Berger, T.; Gebel, J.; Münch, W. Carbon farming in hot, dry coastal areas: An option for climate change mitigation. Earth Syst. Dyn. 2013, 4, 237-251. [CrossRef]

2. Law, B.E.; Hudiburg, T.W.; Berner, L.T.; Kent, J.J.; Buotte, P.C.; Harmon, M.E. Land use strategies to mitigate climate change in carbon dense temperate forests. Proc. Natl. Acad. Sci. USA 2018, 115, 3663-3668. [CrossRef] [PubMed]

3. Johnson, K.H.; Vogt, K.A.; Clark, H.J.; Schmitz, O.J.; Vogt, D.J. Biodiversity and the productivity and stability of ecosystems. Trends Ecol. Evol. 1996, 11, 372-377. [CrossRef]

4. Wright, I.J.; Westoby, M. Differences in seedling growth behaviour among species: Trait correlations across species, and trait shifts along nutrient compared to rainfall gradients. J. Ecol. 1999, 87, 85-97. [CrossRef]

5. Stirling, G.; Wilsey, B. Empirical relationships between species richness, evenness, and proportional diversity. Am. Nat. 2001, 158, 286-299. [CrossRef] [PubMed]

6. Krebs, C.J. Ecology, 5th ed.; Benjamin Cummings: Boston, MA, USA, 2001.

7. Vitousek, P.M.; Howarth, R.W. Nitrogen limitation on land and in the sea: How can it occur? Biogeochemistry 1991, 13, 87-115. [CrossRef]

8. Wardle, D.A.; Bardgett, R.D.; Klironomos, J.N.; Setälä, H.; Van Der Putten, W.H.; Wall, D.H. Ecological linkages between aboveground and belowground biota. Science 2004, 304, 1629-1633. [CrossRef]

9. Forrester, D.I.; Bauhus, J. A Review of Processes Behind Diversity-productivity relationships in forests. Curr. For. Rep. 2016, 2, 45-61. [CrossRef]

10. Harrison, K.A.; Bol, R.; Bardgett, R.D. Preferences for different nitrogen forms by coexisting plant species and soil microbes. Ecology 2007, 88, 989-999. [CrossRef]

11. Parton, W.; Silver, W.L.; Burke, I.C.; Grassens, L.; Harmon, M.E.; Currie, W.S.; King, J.Y.; Adair, E.C.; Brandt, L.A.; Hart, S.C. Global-scale similarities in nitrogen release patterns during long-term decomposition. Science 2007, 315, 361-364. [CrossRef]

12. Sharma, J.; Sharma, Y. Nutrient cycling in forest ecosystems-A review. Agric. Rev. 2004, 25, 157-172. 
13. Rennenberg, H.; Dannenmann, M.; Gessler, A.; Kreuzwieser, J.; Simon, J.; Papen, H. Nitrogen balance in forest soils: Nutritional limitation of plants under climate change stresses. Plant Biol. 2009, 11, 4-23. [CrossRef]

14. Reich, P.B.; Grigal, D.F.; Aber, J.D.; Gower, S.T. Nitrogen mineralization and productivity in 50 hardwood and conifer stands on diverse soils. Ecology 1997, 78, 335-347. [CrossRef]

15. McGuire, A.D.; Melillo, J.M.; Joyce, L.; Kicklighter, D.W.; Grace, A.; Moore, B., III; Vorosmarty, C.J. Interactions between carbon and nitrogen dynamics in estimating net primary productivity for potential vegetation in North America. Glob. Biogeochem. Cycles 1992, 6, 101-124. [CrossRef]

16. Conn, C.; Dighton, J. Litter quality influences on decomposition, ectomycorrhizal community structure and mycorrhizal root surface acid phosphatase activity. Soil Biol. Biochem. 2000, 32, 489-496. [CrossRef]

17. King, R.F.; Dromph, K.M.; Bardgett, R.D. Changes in species evenness of litter have no effect on decomposition processes. Soil Biol. Biochem. 2002, 34, 1959-1963. [CrossRef]

18. Chapman, S.K.; Newman, G.S. Biodiversity at the plant-soil interface: Microbial abundance and community structure respond to litter mixing. Oecologia 2010, 162, 763-769. [CrossRef] [PubMed]

19. Forrester, D.I.; Bauhus, J.; Cowie, A.L. Nutrient cycling in a mixed-species plantation of Eucalyptus globulus and Acacia mearnsii. Can. J. For. Res. 2005, 35, 2942-2950. [CrossRef]

20. Parrotta, J.A. Productivity, nutrient cycling, and succession in single-and mixed-species plantations of Casuarina equisetifolia, Eucalyptus robusta, and Leucaena leucocephala in Puerto Rico. For. Ecol. Manag. 1999, 124, 45-77. [CrossRef]

21. Attiwill, P.M.; Leeper, G.W. Forest Soils and Nutrient Cycles; Melbourne University Press: Carlton, VIC, Australia, 1987.

22. Adams, M.; Attiwill, P. Nutrient cycling and nitrogen mineralization in eucalypt forests of south-eastern Australia. Plant Soil 1986, 92, 341-362. [CrossRef]

23. Forrester, D.I.; Bauhus, J.; Cowie, A.L.; Vanclay, J.K. Mixed-species plantations of Eucalyptus with nitrogen-fixing trees: A review. For. Ecol. Manag. 2006, 233, 211-230. [CrossRef]

24. Isbell, R. The Australian Soil Classification; CSIRO Publishing: Collingwood, Australia, 2016.

25. Warren, R.J.; Giladi, I.; Bradford, M.A. Competition as a mechanism structuring mutualisms. J. Ecol. 2014, 102, 486-495. [CrossRef]

26. Mitchell, K. Quantitative analysis by the point-centered quarter method. arXiv 2010, arXiv:1010.3303.

27. Jimenez, R.R.; Ladha, J.K. Automated elemental analysis: A rapid and reliable but expensive measurement of total carbon and nitrogen in plant and soil samples. Commun. Soil Sci. Plant Anal. 1993, 24, 1897-1924. [CrossRef]

28. Mendham, D.S.; Smethurst, P.J.; Holz, G.K.; Menary, R.C.; Grove, T.S.; Weston, C.; Baker, T. Soil analyses as indicators of phosphorus response in young eucalypt plantations. Soil Sci. Soc. Am. J. 2002, 66, 959-968. [CrossRef]

29. Osanai, Y.; Bougoure, D.S.; Hayden, H.L.; Hovenden, M.J. Co-occurring grass species differ in their associated microbial community composition in a temperate native grassland. Plant Soil 2013, 368, 419-431. [CrossRef]

30. Barton, K.; Barton, M.K. Mu-MIn: Multi-model inference. R Package Version 1.43.6. 2019. Available online: https://cran.r-project.org/web/packages/MuMIn/MuMIn.pdf (accessed on 18 January 2019).

31. Anderson, D.R. Model Based Inference in the Life Sciences: A Primer on Evidence; Springer Science \& Business Media: New York, NY, USA, 2007.

32. Burnham, K.P.; Anderson, D.R. Model Selection and Multimodel Inference: A Practical Information-Theoretic Approach; Springer Science \& Business Media: New York, NY, USA, 2003.

33. Pendall, E.; Osanai, Y.U.I.; Williams, A.L.; Hovenden, M.J. Soil carbon storage under simulated climate change is mediated by plant functional type. Glob. Chang. Biol. 2011, 17, 505-514. [CrossRef]

34. Osanai, Y.; Flittner, A.; Janes, J.K.; Theobald, P.; Pendall, E.; Newton, P.C.; Hovenden, M.J. Decomposition and nitrogen transformation rates in a temperate grassland vary among co-occurring plant species. Plant Soil 2012, 350, 365-378. [CrossRef]

35. Dijkstra, F.A.; Hobbie, S.E.; Reich, P.B. Soil processes affected by sixteen grassland species grown under different environmental conditions. Soil Sci. Soc. Am. J. 2006, 70, 770-777. [CrossRef]

36. Freschet, G.T.; Cornwell, W.K.; Wardle, D.A.; Elumeeva, T.G.; Liu, W.; Jackson, B.G.; Onipchenko, V.G.; Soudzilovskaia, N.A.; Tao, J.; Cornelissen, J.H. Linking litter decomposition of above-and below-ground organs to plant-soil feedbacks worldwide. J. Ecol. 2013, 101, 943-952. [CrossRef] 
37. García-Palacios, P.; Maestre, F.T.; Kattge, J.; Wall, D.H. Climate and litter quality differently modulate the effects of soil fauna on litter decomposition across biomes. Ecol. Lett. 2013, 16, 1045-1053. [CrossRef] [PubMed]

38. Makkonen, M.; Berg, M.P.; Handa, I.T.; Hättenschwiler, S.; Van Ruijven, J.; Van Bodegom, P.M.; Aerts, R. Highly consistent effects of plant litter identity and functional traits on decomposition across a latitudinal gradient. Ecol. Lett. 2012, 15, 1033-1041. [CrossRef] [PubMed]

39. Hobbie, S.E. Effects of plant species on nutrient cycling. Trends Ecol. Evol. 1992, 7, 336-339. [CrossRef]

40. Wardle, D.; Bonner, K.; Nicholson, K. Biodiversity and plant litter: Experimental evidence which does not support the view that enhanced species richness improves ecosystem function. Oikos 1997, 79, 247-258. [CrossRef]

41. Jiang, L.; Wan, S.; Li, L. Species diversity and productivity: Why do results of diversity-manipulation experiments differ from natural patterns? J. Ecol. 2009, 97, 603-608. [CrossRef]

42. Hyvönen, R.; Ågren, G.I.; Linder, S.; Persson, T.; Cotrufo, M.F.; Ekblad, A.; Freeman, M.; Grelle, A.; Janssens, I.A.; Jarvis, P.G.; et al. The likely impact of elevated $\left[\mathrm{CO}_{2}\right]$, nitrogen deposition, increased temperature and management on carbon sequestration in temperate and boreal forest ecosystems: A literature review. New Phytol. 2007, 173, 463-480. [CrossRef] [PubMed]

43. Nordin, A.; Näsholm, T.; Ericson, L. Effects of simulated N deposition on understorey vegetation of a boreal coniferous forest. Funct. Ecol. 1998, 12, 691-699. [CrossRef]

44. Matson, P.; Lohse, K.A.; Hall, S.J. The globalization of nitrogen deposition: Consequences for terrestrial ecosystems. Ambio 2002, 31, 113-119. [CrossRef] [PubMed]

45. Wedin, D.A.; Tilman, D. Species effects on nitrogen cycling: A test with perennial grasses. Oecologia 1990, 84, 433-441. [CrossRef] [PubMed]

46. Temperton, V.M.; Mwangi, P.N.; Scherer-Lorenzen, M.; Schmid, B.; Buchmann, N. Positive interactions between nitrogen-fixing legumes and four different neighbouring species in a biodiversity experiment. Oecologia 2007, 151, 190-205. [CrossRef] [PubMed]

47. Koch, A.J.; Driscoll, D.A.; Kirkpatrick, J. Estimating the accuracy of tree ageing methods in mature Eucalyptus obliqua forest, Tasmania. Aust. For. 2008, 71, 147-159. [CrossRef]

48. Bouillet, J.-P.; Laclau, J.-P.; Gonçalves, J.L.d.M.; Voigtlaender, M.; Gava, J.L.; Leite, F.P.; Hakamada, R.; Mareschal, L.; Mabiala, A.; Tardy, F.; et al. Eucalyptus and Acacia tree growth over entire rotation in singleand mixed-species plantations across five sites in Brazil and Congo. For. Ecol. Manag. 2013, 301, 89-101. [CrossRef]

49. Epron, D.; Nouvellon, Y.; Mareschal, L.; Moreira, R.M.e.; Koutika, L.-S.; Geneste, B.; Delgado-Rojas, J.S.; Laclau, J.-P.; Sola, G.; Gonçalves, J.L.d.M.; et al. Partitioning of net primary production in Eucalyptus and Acacia stands and in mixed-species plantations: Two case-studies in contrasting tropical environments. For. Ecol. Manag. 2013, 301, 102-111. [CrossRef]

50. Ryan, M.; Binkley, D.; Fownes, J.H. Age-related decline in forest productivity: Pattern and process. In Advances in Ecological Research; Elsevier: Amsterdam, The Netherlands, 1997; Volume 27, pp. 213-262.

51. Aerts, R.; Honnay, O. Forest restoration, biodiversity and ecosystem functioning. BMC Ecol. 2011, 11, 29. [CrossRef] [PubMed]

52. Villela, D.M.; Nascimento, M.T.; De Aragao, L.E.O.; Da Gama, D.M. Effect of selective logging on forest structure and nutrient cycling in a seasonally dry Brazilian Atlantic forest. J. Biogeogr. 2006, 33, 506-516. [CrossRef]

53. Tilman, D.; Reich, P.; Knops, J.; Wedin, D.; Mielke, T.; Lehman, C. Diversity and productivity in a long-term grassland experiment. Science 2001, 294, 843-845. [CrossRef]

54. Cardinale, B.J.; Wright, J.P.; Cadotte, M.W.; Carroll, I.T.; Hector, A.; Srivastava, D.S.; Loreau, M.; Weis, J.J. Impacts of plant diversity on biomass production increase through time because of species complementarity. Proc. Natl. Acad. Sci. USA 2007, 104, 18123-18128. [CrossRef]

55. Lowman, M.D. Litterfall and leaf decay in three Australian rainforest formations. J. Ecol. 1988, 76, 451-465. [CrossRef]

56. Clark, D.A.; Brown, S.; Kicklighter, D.W.; Chambers, J.Q.; Thomlinson, J.R.; Ni, J.; Holland, E.A. Net primary production in tropical forests: An evaluation and synthesis of existing field data. Ecol. Appl. 2001, 11, 371-384. [CrossRef] 
57. Bini, D.; Dos Santos, C.A.; Bouillet, J.-P.; De Morais Goncalves, J.L.; Cardoso, E.J.B.N. Eucalyptus grandis and Acacia mangium in monoculture and intercropped plantations: Evolution of soil and litter microbial and chemical attributes during early stages of plant development. Appl. Soil Ecol. 2013, 63, 57-66. [CrossRef]

58. Forrester, D.; Pares, A.; O’hara, C.; Khanna, P.; Bauhus, J. Soil organic carbon is increased in mixed-species plantations of Eucalyptus and nitrogen-fixing Acacia. Ecosystems 2013, 16, 123-132. [CrossRef]

(C) 2019 by the authors. Licensee MDPI, Basel, Switzerland. This article is an open access article distributed under the terms and conditions of the Creative Commons Attribution (CC BY) license (http://creativecommons.org/licenses/by/4.0/). 